\title{
Influenza pandemic preparedness in the World Health Organization Eastern Mediterranean Region
}

\author{
Wasiq Khan, ${ }^{1}$ Amira El Rifay, ${ }^{2}$ Mamunur Malik ${ }^{3}$ and Ghazi Kayali 4,5
}

${ }^{1}$ Department of Health, University of Bath, United Kingdom. ${ }^{2}$ Center of Excellence for Influenza Viruses, Child Health department National Research Centre, Giza, Egypt. 3World Health Organization, Regional Office for the Eastern Mediterranean, Cairo, Egypt. ${ }^{4}$ Department of Epidemiology, University of Texas Health Sciences Center, Houston, Texas, United States of America. ${ }^{5}$ Human Link, Hazmieh, Lebanon. (Correspondence to: Ghazi Kayali: ghazi@human-link.org).

\begin{abstract}
Background: Preparedness is key to controlling influenza pandemics and epidemics.

Aims: A comprehensive literature review was conducted to analyse the response and preparedness to influenza pandemics in the World Health Organization Eastern Mediterranean Region (WHO/EMR).

Methods: Published and grey literatures were searched in PubMed, Scopus, and Google scholar, and the WHO/EMR online databases. International and national plans were searched via official websites of the relevant ministries of the countries.

Results: We found that the response from EMR countries was minimal and scientific papers published were limited. Moreover, most of those papers studied the preparedness plan partially by focusing on one or more elements such as infection control measures and vaccines, or were directed to certain populations such as health workers. Continuous active surveillance is ignored in most of the countries although it was the most important lesson learned from the pandemic.

Conclusions: The national preparedness plans should be updated, taking guidance from the findings in the present report, to address any emerging pandemic virus as well as attending to surges of seasonal influenza cases.

Keywords: influenza, preparedness plans, Middle East, research and pandemic, Eastern Mediterranean Region

Received: 14/06/17; accepted: 06/12/17

Citation: Khan W; El Rifay A; Malik M; Kayali G. Influenza pandemic preparedness in the World Health Organization Eastern Mediterranean Region. East Mediterr Health J. 2019;25(8):583-590. https://doi.org/10.26719/emhj.18.070

Received: 14/06/17; accepted: 06/12/17

Copyright $($ W World Health Organization (WHO) 2019. Some rights reserved. This work is available under the CC BY-NC-SA 3.0 IGO license (https:// creativecommons.org/licenses/by-nc-sa/3.o/igo).
\end{abstract}

\section{Introduction}

Although the last influenza $\mathrm{H} 1 \mathrm{~N} 1$ pandemic in 2009 was mild, fear prevails that the next one might not be $(1,2)$. Due to frequent mutations and reassortment in its genome, influenza is a continuously evolving virus (3). Predicting when or where an influenza pandemic may arise, or even which strain will be the culprit is a difficult task (4).

Following the emergence of avian influenza $\mathrm{H}_{5} \mathrm{~N} 1$ and the fear of its pandemic potential, having an adequate preparedness plan became a priority as the World Health Organization (WHO) urged every country to develop and maintain an up-to-date national influenza preparedness plan, and provided guidance on plan content (5). Comprehensive research on the epidemiology, medical anthropology, and pandemic management policies was conducted and resulted in the production of international and national plans (6). However, the pandemic did not turn out as expected, leading to re-evaluation of preparedness mechanisms (6). Two years after the 2009 $\mathrm{H} 1 \mathrm{~N} 1$ pandemic, the published data around this issue exceeded 2500 articles around the world in an attempt to understand the pandemic dynamics (7).

The location of the WHO Eastern Mediterranean Region (EMR) makes it important for influenza A virus circulation, as EMR countries lie under four of the eight global migratory bird flyways: Central Asia-India, West Asia-Africa, Mediterranean-Black Sea, and East Atlantic (8). The pandemic burden became recently more significant in the EMR with the sudden surge in human cases of $\mathrm{H}_{5} \mathrm{~N} 1$ in Egypt. Earlier reviews of pandemic preparedness plans in the region reveal that WHO EMR's response to pandemic $(\mathrm{H} 1 \mathrm{N1}) 2009$ was successful in many ways, yet lacking in others. Overall, the response to the $\mathrm{H}_{1} \mathrm{~N} 1$ pandemic was a learning experience on which capacity to face future events in the Region can be built and strengthened. In order to understand the preparedness and response to influenza outbreaks and pandemics in the WHO EMR, with particular reference to challenges and constraints specific to the Region, we reviewed peer-reviewed scientific literature, nonpeer-reviewed literature, and international and national plans. We then issued guidance for updating the current preparedness plans for the countries of the EMR.

\section{Methods}

\section{Search strategy}

Searching the literature and preparedness plans for the Region was performed using the search terms in three languages (Arabic, English and French) for all the available published data up to 2016. The relevant records only 
were maintained after reviewing the full text of each. Most of the deleted records were due to irrelevant subject matter.

First, the peer-reviewed and the non-peer-reviewed scientific literature published on influenza pandemic preparedness was searched in the following databases: PubMed, Scopus and Google scholar (all fields). The search terms were "pandemic influenza", "preparedness" AND "country name" (Afghanistan, Bahrain, Djibouti, Egypt, Iran, Iraq, Jordan, Kuwait, Lebanon, Libya, Morocco, Oman, Pakistan, Palestine, Qatar, Saudi Arabia, Somalia, South Sudan, Sudan, Syria, Tunisia, United Arab Emirates (UAE), and Yemen). An additional search term "Middle East" was also used to avoid excluding any multinational publication. An alternative country name of certain countries was also used to avoid excluding publications when, for instance, if the French name of the country was commonly used. These alternative names were: Liban, Maroc, Gaza and West Bank, Syrie, Tunisie, and Emirats. Then the search was expanded by amendment of the search terms into "pandemic influenza" AND "country name" and this in turn yielded more documents. Finally, search terms "epidemic influenza” AND “country name' were used resulting in more publications from the Region.

Second, the WHO EMR databases, Index Medicus for the Eastern Mediterranean Region (IMEMR), WHO EMR Publications (EMRPUB), and WHO EMR Institutional Digital Repository (IDRNET), were searched for published articles using search term "influenza preparedness".

Third, international pandemic preparedness plans and checklists were searched via official websites that compile such documents (e.g., http://www.who.int, http://www.cdc.gov, http://ecdc.europa.eu/en/Pages/ home.aspx, and http://www.flu.gov/).

National preparedness plans in the EMR were searched in the official ministry of health websites for the different countries using the same search terms but in different languages (Arabic and English), since some national plans are available only in Arabic. Google was used first to follow the links to the published plans or to access the official ministry of health website for each country.

\section{Published peer-reviewed and non-peer- reviewed scientific literature}

Publications related to pandemic and/or epidemic preparedness and response were limited to seven countries (Bahrain, Egypt, Islamic Republic of Iran, Palestine, Pakistan, Saudi Arabia and United Arab Emirates). A total of 72 articles were analysed out of which 22 (30.5\%) were non-peer-reviewed publications. Few articles were published before 2009, after which the field gained more attention after the pandemic, when 65 articles (90\%) were published from 2009 onwards. Saudi Arabia led the other countries by 41 (56.9\%) records and was followed by Islamic Republic of Iran by 18 (25\%) records and Egypt by $6(8.3 \%)$ records. Other EMR countries had less than five records. Out of a total of 72 records from seven countries, $21(29.1 \%)$ records fell under the Knowledge, Attitude, and Practice (KAP) type of study. Infection control measures was the top priority for researchers in Saudi Arabia resulting in several articles related to awareness, public behaviour during mass gatherings, and vaccination policy. Only a few records covered thoroughly issues related to preparedness plans.

A few Iranian articles focused on the lessons learned from the pandemic, mostly through conducting literature reviews or reviews of official reports from WHO and the Iranian disease control center (9). Assessing public health information about the pandemic showed that the mass media is the most effective way in disseminating emergency notifications (10).

Egyptian researchers had six publications, out of which two non-peer-reviewed publications were found. One criticized the policy adopted by local authorities in response to the $2009 \mathrm{H1N} 1$ pandemic (11). The other assessed the knowledge level of medical students regarding preventive measures of $\mathrm{HiN} 1$ (12). Another three published articles from Egypt were KAP type $(13,14)$. Only one review discussed the epidemic control measures in Egypt and concluded that unless a global collaboration exists, HPAI $\mathrm{H}_{5} \mathrm{~N} 1$ virus in Egypt will continue to compromise the poultry industry, endanger public health, and pose a serious pandemic threat (15).

Bahrain publications were limited to KAP type $(16,17)$, while Pakistan published one article in which authors suggested a model for multiple control strategies for prevention of pandemics (18). One non-peer-reviewed publication from the United Arab Emirates tried to estimate the required vaccine in case of influenza epidemic by using mathematical models (19).

Only two articles were generated from collaboration between three countries (Palestine, Jordan, and Israel) and both were produced by members of the Middle East Consortium on Infectious Disease Surveillance (MECIDS) in 2006 and 2013 respectively $(5,20)$. Following the avian influenza incidents in 2005-2006, MECIDS conducted a series of national pandemic influenza tabletop exercises to identify gaps in preparedness and cross-sectoral cooperation and to develop a list of priority actions to improve preparedness and response in 2007 and 2008.

\section{Non-peer-reviewed literature publications from EMR databases}

The WHO Regional Office for the Eastern Mediterranean had organized preparedness sub-regional meetings up to 2016. Reports generated from these meetings were published and available on IDRNET database (21-24). Moreover, a regional strategy on preparedness and response was issued and contained steps for protection of the international community against pandemic influenza according to International Health Regulations (IHR) (2005). As for the IMEMR database, eight articles were available, four of which were KAP type evaluating the knowledge lev- 
el and preventive measures of influenza adopted by the general population, school students, medical students, and pilgrims. One publication illustrated the early outcomes of pandemic HiN1 surveillance in the United Arab Emirates providing the incidence of confirmed $\mathrm{H}_{1} \mathrm{~N}_{1}$ cases (21). Another two publications described the pandemic history and the characteristics of the virus $(22,23)$.

\section{Pandemic preparedness plans in EMR}

Search for national preparedness plans in the Region resulted in eight plans for the following countries (Egypt, Islamic Republic of Iran, Lebanon, Jordan, Palestine, Saudi Arabia, Oman and Yemen) out of the 23 EMR countries, and were published between 2006 and 2016. All the published plans were produced by the ministry of health of the country using checklists and/or tools from international bodies such as WHO and CDC.

All the examined plans followed the international guidelines but failed to cover the basic elements comprehensively. The priority of most of the plans was human infections and included infectioncontrol measures, pharmacological issues, and crises management algorithms. Only the Egyptian and Saudi Arabian plans discussed both animal and human influenza control and sector integration was planned in case of crises. Ethical and legal issues, special country circumstances, border screening, integration of international bodies were almost ignored. Continuous active surveillance was ignored in most of the countries after the post-pandemic phase although it was the most important lesson learned from the pandemic (24). Communication and collaboration of assigned authorities in almost all plans were taken into consideration, but risk communication was not always clearly defined.

\section{Improving future planning}

This review revealed several common themes that required improvement in the influenza preparedness plans of the WHO EMR Member States. Those themes were: epidemiologic surveillance, virologic surveillance, risk communication, infection control, vaccines, antivirals, hospitalization and critical care, inter-country coordination, regional and international coordination, plan revision and evaluation, and lack of focus on epidemic influenza.

\section{Epidemiologic surveillance}

Very few plans and publications discussed epidemiologic surveillance in the Region. Surveillance is a key function of monitoring seasonal influenza, pandemic preparedness planning, and IHR compliance. Surveillance has been highlighted as an area that requires improvement in several regions $(25,26)$. All country plans should describe their current epidemiologic surveillance system and countries lacking systematic, sustainable surveillance should implement that immediately. Plans should then describe how epidemiologic surveillance would expand during pandemic response. Attention should be directed at the frequency of generating reports and how region- al surveillance would be tied up to central surveillance units. Frequency of reporting during a pandemic needs to be quicker to enable the decision makers nationally and globally to monitor the pandemic and respond accordingly.

\section{Virologic surveillance}

Capacity for laboratory surveillance has been highlighted as a key to success in the WHO European Region (EURO), while it was an area that needed improvement in the WHO African Region (AFRO) $(25,27,28)$. Countries with no virologic surveillance should implement that immediately. Surge capacity for virologic surveillance should be clearly identified especially that during a pandemic, sampling and testing would be dramatically increased to cover diagnosis of disease as well as virus characterization. Little evidence was found on reports analyzing virologic surveillance data, hence indicating that there is not enough virologic surveillance occurring in the Region. Virologic surveillance, especially at initial phases of a pandemic, is essential for understanding the viral characteristics which is important for vaccine preparation.

At later stages, virologic surveillance is key to understanding whether any genetic and antigenic drift is occurring. In the plan, countries must clearly state which laboratories will be utilized in the surge and they are encouraged to include not only public health laboratories but also research and private laboratories with influenza capacity. The related logistics must be clearly detailed in the plan including but not limited to logistics of sample collection, sample transportation, availability of lab kits and reagents, and result reporting mechanisms.

\section{Risk communication}

During a pandemic, risk communication is key to disperse information to all stakeholders. The analysis in this report indicated that pandemic risk communication is sparse in the EMR as is the case in African and Asia-Pacific regions (26-28). The countries' pandemic plans must clearly detail all the risk communication methods to be utilized during a pandemic. This should include mechanisms of communication with the public, care providers, and other stakeholders.

\section{Infection control}

The primary role of pandemic preparedness is to limit or stop viral transmission. If disease requires hospitalization, then nosocomial transmission must be minimized. Sparse evidence was found on how infection control would be enhanced in hospitals dealing with infected patients. Plans should clearly define infection control policies to be enacted, how infection control supplies would be stockpiled and dispersed, which hospitals to be designated to primarily receive patients, and other necessary measures for infection control. Furthermore, plans for border screening should be in place including setting up proper quarantine facilities dedicated for receiving incoming cases of disease in conjunction with other infection control measures. Finally, plans should include 
insight on transmission and infection control in the community settings and how this would be communicated with key community players $(26,30)$.

\section{Vaccines}

Having plans for stockpiling and distribution of vaccines is key to proper response $(27,30)$. In the event of a pandemic, it is highly likely that the current vaccines would not be effective and hence there would be a delay between virus detection and availability of vaccines. Even when a vaccine is prepared, quantities will not be sufficient to cover the entire population. Little was found in relation to vaccine and antiviral policies in this search. Countries should include pandemic vaccination policies that determine the target populations that should receive the vaccine, the number of dozes required, vaccine storage units, vaccine dispersal facilities, and vaccine uptake monitoring. Furthermore, seasonal influenza vaccination policies should be revised and enforced.

\section{Antivirals}

For antivirals, countries should work under the assumption that current antivirals would be effective against an upcoming pandemic virus. It is highly unlikely that a novel antiviral drug would be available swiftly if the pandemic strain is resistant to the current ones. Hence, pandemic preparedness must include plans for stockpiling currently available antiviral drugs as this is a key to a successful response, only vaccines and antiviral drugs are clearly efficacious in preventing infection or treating illness $(26,29,30)$. This should also include where the stocks would be stored, how they will be dispersed, and the guidelines for clinical use. Other drugs such as antibiotics to fight secondary bacterial infections and pneumonia, antipyretics, and anti-inflammatory drugs should be also included in planning (29).

\section{Hospitalization and critical care}

It is highly likely that in case of a pandemic, a surge in utilization of healthcare resources and personnel would occur $(26,29)$. This would include a surge in hospital bed use as well as intensive care beds. Evidence of such planning in the EMR was negligible. Plans should carefully consider what to do in case of such surge taking into account other sectors that could assist in healthcare such as the private and military sectors.

\section{Inter-country coordination}

In several countries, non-governmental, academic, and private institutions play a significant role in public health, hence coordination and utilization of such institutions is necessary. All this mandates having clearly defined channels of communication and coordination, as well as pre-defining how decision-making and leadership would be structured. A pandemic preparedness evaluation exercise in Thailand revealed the importance of planning at all administrative levels (31). Very few of the reviewed plans had elements describing how coordination will take place with sectors other than health.
In countries that are under a federal law, that are geographically large, that are heavily populated, or that are religiously or ethnically diverse, sub-national plans must be included and then incorporated and linked to the national plan.

\section{Ethical and legal frameworks}

During a pandemic, situations necessitating restricting people movement, mandating quarantines, mandating certain infection control measures, mandating certain clinical interventions, among others may arise. Such issues require having provisions to obtain the necessary ethical and legal frameworks for implementations. Furthermore, having a clear legal framework is essential to determine leadership and proper channels of communication and coordination. Lack of clear legal frameworks was highlighted as a weakness in influenza preparedness in Africa (25).

\section{Regional and international coordination}

Little evidence of regional collaboration was found. Furthermore, influenza pandemic response is a global effort coordinated by WHO with significant contributions from other global influenza authorities. Regional plans must indicate how coordination with WHO collaborating centers, and WHO reference laboratories will be handled. Plans must be compatible with IHR and other globally recognized health treaties.

\section{Plan revision and evaluation}

None of the reviewed plans clearly stated when and how the plan would be evaluated and revised. Furthermore, none of the plans made provisions for mock-exercises or simulations. Plans should clearly mention this and make use of epidemic and outbreak situations that occur frequently in the Region to activate all or parts of the plan. Lessons learned from such exercises would help improve pandemic preparedness plans. Furthermore, data collected from outbreak, epidemic, or pandemic response should be readily available to researchers who can provide analysis, expert opinion, and design specifically-tailored research aimed at improving various aspects of pandemic preparedness.

\section{Lack of focus on epidemic influenza}

Our analysis showed that preparedness and response efforts were largely focused on pandemic influenza. All findings were related to either the $2009 \mathrm{H} 1 \mathrm{~N} 1$ pandemic or the arrival of $\mathrm{H}_{5} \mathrm{~N} 1$ to the region in 2005-2006. Preparedness and response to outbreaks of seasonal influenza are largely lacking. Focus of the plan should not be on a single virus as this might lead to confusion if a different virus emerged. This is what happened during the 2009 $\mathrm{H}_{1} \mathrm{~N}_{1}$ pandemic as focus was on $\mathrm{H}_{5} \mathrm{~N}_{1}$ for a long time while the $\mathrm{H} 1 \mathrm{~N} 1$ pandemic virus did not have the same epidemiology of $\mathrm{H}_{5} \mathrm{~N} 1$ (29).

The findings described in the above themes are recommended to be used as a guidance to assist EMR countries in updating or preparing their national 
influenza pandemic preparedness plans. These are summarized as an influenza preparedness planning guidance document in Table 1.

\section{Conclusion}

This review of the published peer-reviewed literature, non-peer-reviewed literature, and countries' influenza preparedness plans revealed that influenza preparedness and response remain weak in the EMR. An essential first step would be updating the national influenza preparedness plans guided by the findings of this report.

Funding: This work was supported under the Pandemic Influenza Preparedness Partnership Contributions for implementation activities in the WHO Eastern Mediterranean Region. The funder had no role in study design and collection, analysis, and interpretation of data and in writing the manuscript.

Competing interests: None declared.

\begin{tabular}{|c|c|c|}
\hline Item & Goal & Content \\
\hline Introduction and objectives & $\begin{array}{l}\cdot \text { Informative } \\
\text { introduction. } \\
\text { - Objectives. }\end{array}$ & $\begin{array}{l}\text { The plan introduction should cover the essential information focusing on the local and } \\
\text { regional situation of the disease. } \\
\text { The plan should identify the preparedness goals and provide a formal risk assessment. } \\
\text { Clearly indicate when the plan would be activated. } \\
\text { The risk assessment should be based on the WHO Tool for Influenza Pandemic Risk } \\
\text { Assessment (TIPRA) (http://apps.who.int/iris/bitstream/10665/250130/1/WHO-OHE-PED-GIP- } \\
\text { 2016.2-eng.pdf?ua=1). } \\
\text { Risk assessment trigger should be based on TIPRA's epidemiological and virological triggers } \\
\text { (TIPRA document, page 10). }\end{array}$ \\
\hline Risk assessment & $\begin{array}{l}\text { - Identify risk factors } \\
\text { for pandemics/ } \\
\text { epidemics and plans } \\
\text { for mitigation. } \\
\text { - Identify a } \\
\text { panel of experts } \\
\text { (epidemiologists, } \\
\text { veterinarians, } \\
\text { virologists, } \\
\text { clinicians, } \\
\text { immunologists, } \\
\text { pharmacologists, } \\
\text { molecular } \\
\text { virologists). }\end{array}$ & $\begin{array}{l}\text { Conduct a risk assessment exercise based on TIPRA. } \\
\text { List names and contact information of primary and secondary experts to assist in conducting } \\
\text { TIPRA exercises. }\end{array}$ \\
\hline Item & Goal & Content \\
\hline Epidemiological surveillance & $\begin{array}{l}\text { - A functional } \\
\text { surveillance system } \\
\text { is an integral } \\
\text { aspect of the } \\
\text { national influenza } \\
\text { plan to provide } \\
\text { early detection of } \\
\text { emerging viruses } \\
\text { and to monitor } \\
\text { seasonal influenza. }\end{array}$ & $\begin{array}{l}\text { Describe the current epidemiological surveillance system. } \\
\text { Explain how epidemiological surveillance would expand during pandemic response. }\end{array}$ \\
\hline Virological surveillance & $\begin{array}{l}\text { - Essential for } \\
\text { understanding the } \\
\text { viral characteristics } \\
\text { which is important } \\
\text { for vaccine } \\
\text { preparation and } \\
\text { antiviral sensitivity. }\end{array}$ & $\begin{array}{l}\text { Describe the current epidemiological surveillance system. } \\
\text { State which laboratories will be utilized in a surge. The related logistics must be clearly } \\
\text { detailed including, but not limited to, logistics of sample collection, sample transportation, } \\
\text { availability of laboratory kits and reagents, and result reporting mechanisms. }\end{array}$ \\
\hline $\begin{array}{l}\text { Sub-national surveillance } \\
\text { system }\end{array}$ & $\begin{array}{l}\text { - Sub-national } \\
\text { surveillance } \\
\text { systems are crucial } \\
\text { for complete } \\
\text { surveillance data }\end{array}$ & Describe the surveillance systems at the sub-national level. \\
\hline $\begin{array}{l}\text { Communication command } \\
\text { strategy }\end{array}$ & $\begin{array}{l}\text { - Strong } \\
\text { communication } \\
\text { strategy is a key } \\
\text { to a coordinated } \\
\text { response. }\end{array}$ & $\begin{array}{l}\text { Pandemic planning committee comprising stakeholders from both private and public sectors. } \\
\text { The plan should identify means of communications, what should be the role of each member } \\
\text { of the committee during a pandemic or an epidemic. }\end{array}$ \\
\hline
\end{tabular}




\section{Table 1 Influenza preparedness planning guidance document (concluded)}

\begin{tabular}{|c|c|c|}
\hline Item & Goal & Content \\
\hline Risk communication & $\begin{array}{l}\text { - Provide and } \\
\text { exchange relevant } \\
\text { information to the } \\
\text { public, partners, } \\
\text { and stakeholders in } \\
\text { order to allow them } \\
\text { to make informed } \\
\text { decisions. }\end{array}$ & $\begin{array}{l}\text { Detail all the risk communication methods to be utilized during a pandemic. It is not enough } \\
\text { to rely on the media or publish awareness pamphlets. This should include mechanisms of } \\
\text { communication with the public, care providers, and other stakeholders. } \\
\text { Algorithm with available contact data (rapid response). }\end{array}$ \\
\hline $\begin{array}{l}\text { Collaboration and inter- } \\
\text { country coordination }\end{array}$ & $\begin{array}{l}\text { - Coordination } \\
\text { across sectors. } \\
\text { using a one health } \\
\text { approach. } \\
\text { - Maintenance of } \\
\text { essential services. }\end{array}$ & $\begin{array}{l}\text { Engagement of decision-makers and assigned authorities and include non-governmental, } \\
\text { academic, and private institutions. } \\
\text { Sub-national plans must be included and then incorporated and linked to the national plan. }\end{array}$ \\
\hline $\begin{array}{l}\text { Regional and international } \\
\text { coordination }\end{array}$ & $\begin{array}{l}\text { - To integrate the } \\
\text { plan with regional } \\
\text { and international } \\
\text { efforts }\end{array}$ & $\begin{array}{l}\text { Indicate how coordination with WHO/EMRO, WHO collaborating centres, and WHO } \\
\text { reference laboratories will be handled. Plans must be compatible with IHR and other globally } \\
\text { recognized health treaties. } \\
\text { State how findings will be shared with WHO. }\end{array}$ \\
\hline Special/vulnerable population & $\begin{array}{l}\text { - To protect } \\
\text { vulnerable groups. }\end{array}$ & $\begin{array}{l}\text { Include provisions for vulnerable groups in countries suffering from political circumstances } \\
\text { (refugees ) or mass gathering (Hajj). }\end{array}$ \\
\hline Ethical and legal frameworks & $\begin{array}{l}\text { - Clear legal } \\
\text { framework } \\
\text { is essential } \\
\text { to determine } \\
\text { leadership and } \\
\text { proper channels of } \\
\text { communication and } \\
\text { coordination. }\end{array}$ & $\begin{array}{l}\text { Describe legal and ethical frameworks that will take effect if, for example, restricting people } \\
\text { movement, mandating quarantines, mandating certain infection control measures, and } \\
\text { mandating certain clinical interventions will be implemented. }\end{array}$ \\
\hline
\end{tabular}

\section{Item}

Health care response

Case identification and management

Infection contro

Pharmacological intervention

Laboratory capacity

Revision of the plan

Checklist and tools

\section{Goal}

- To provide health care services

- Maintenance of during pandemic/ epidemic.

- Accurate and early diagnosis of cases.

- Prevent transmission. health services.

\section{Content}

Estimate health capacities to be utilized with consideration of NGOs and private sector together with governmental hospitals.

Describe alternative health sectors that can assist to cover the surge of health care services needed.

Trained personnel (medical staff, health care workers, laboratory staff, volunteers).

Definition of confirmed or suspected cases.

Diagnostic tools and checklists.

Case management algorithm.

Define infection control policies to be enacted, how infection control supplies would be stockpiled and dispersed, which hospitals to be designated to primarily receive patients, patient triaging, and other necessary measures for infection control.

Plans for border screening should be in place including setting up proper quarantine facilities dedicated for receiving incoming cases of disease.

Stockpiled personal protective equipment.

Plans for non-pharmacological community-based interventions.

Describe the current policy for seasonal influenza vaccination.

Estimate the number of doses required if a novel vaccine is introduced in response to a pandemic and define the populations to receive it.

Describe the logistics of vaccine dispersal.

- Vaccine

requirements if

a new vaccine is

needed.

- Provide and

maintain stockpiled

antivirals, anti-

biotics, and other

relevant medications

- Laboratory capacity

is key for pandemic preparedness.

- Evaluation to address any gaps.

- Checklists and tools, as applicable, needed to aid plan execution.
Describe how drugs are stockpiled and how distribution will occur during a pandemic/ epidemic.

Identify the current network of national and sub-national laboratories where influenza diagnostics are performed.

Identify the network of laboratories, including private or academic laboratories, that can assist in case of a surge.

Provide clear instructions for sample collection, storage, diagnostics algorithms, and result reporting.

Provide frequencies of plan simulations and exercises, evaluation, and revision.

Provide pre-designed checklist and tools.

Include TIPRA tools. 


\section{Préparation à la pandémie de grippe dans la Région de l’OMS pour la Méditerranée orientale}

\section{Résumé}

Contexte : La préparation est essentielle pour lutter contre les épidémies et les pandémies de grippe.

Objectifs : Une étude exhaustive de la littérature a été menée afin d'analyser la riposte et la préparation aux pandémies de grippe dans la Région de l'OMS pour la Méditerranée orientale.

Méthodes : Des recherches ont été effectuées dans la littérature publiée et grise dans PubMed, Scopus et Google Scholar ainsi que dans les bases de données en ligne qui concernent la Région de l'OMS pour la Méditerranée orientale. Les plans internationaux et nationaux ont également fait l'objet de recherches via les sites Web officiels des ministères concernés des pays.

Résultats : Nous avons constaté que la riposte des pays de la Région de la Méditerranée orientale était minimale et que le nombre d'articles scientifiques publiés était limité. De surcroît, la majorité des articles présentait une analyse partielle du plan de préparation en mettant l'accent sur un ou plusieurs aspects tels que les mesures de lutte contre les infections et les vaccins, ou visait certaines populations comme les agents de santé. La plupart des pays ne tiennent pas compte de la nécessité de mettre en place une surveillance active et continue, bien que ce soit l'enseignement le plus important à retenir de la pandémie.

Conclusions : Les plans de préparation nationaux doivent être mis à jour sur la base des conclusions du présent article, afin de traiter l'apparition de tout virus pandémique et de faire face aux fortes augmentations de cas de grippe saisonnière.

$$
\begin{aligned}
& \text { التأهب لجائحة الإنفلونزا في إقليم شرق المتوسط لمنظمة الصحة العالمية } \\
& \text { واثق خان، أميرة الرفاعي، مأمون مالك، غازي كيالي } \\
& \text { الخلاصة } \\
& \text { الخلفية: يعد التأهب أمرًا رئيسيًا في مكافحة أوبئة الإنفلونزا. }
\end{aligned}
$$

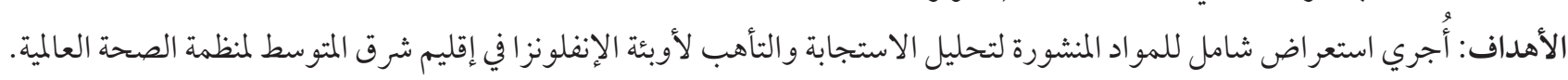

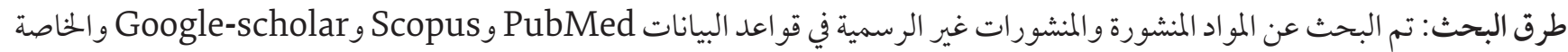

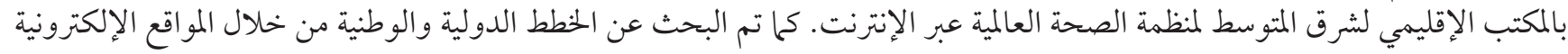

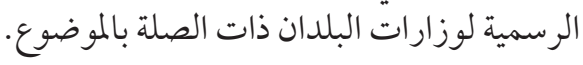

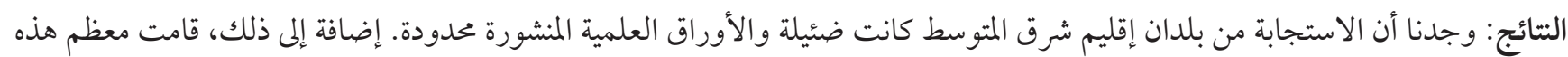

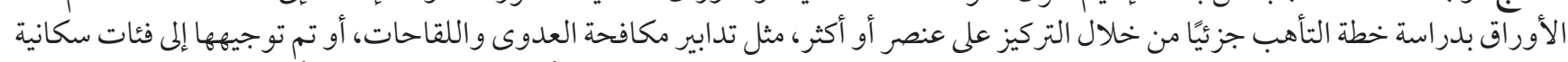

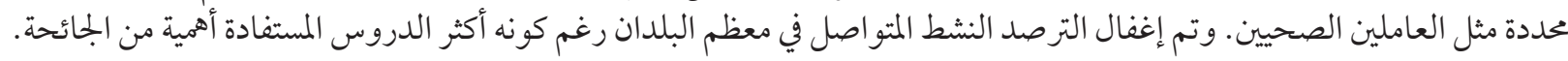

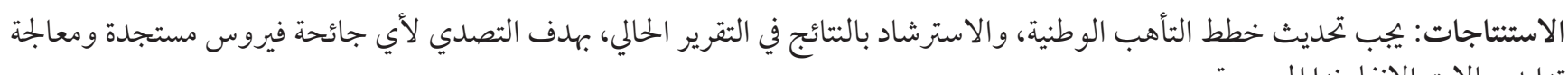

$$
\begin{aligned}
& \text { تز ايد حالات الإنفلونزا الموسمية. }
\end{aligned}
$$

\section{References}

1. Centers for Disease Control and Prevention. Influenza epidemiology and prevention of vaccine-preventable disease. Hamborsky J, Kroger A, Wolfe S, eds. 13th ed. Washington DC: Public Health Foundation, 2015.

2. Taubenberger JK, Morens DM. Influenza: the once and future pandemic. Public Health Rep. 2010;125(3_suppl) Suppl 3:15-26. http://dx.doi.org/10.1177/00333549101250S305

3. Stöhr K. Influenza-WHO cares. Lancet Infect Dis. 2002;2(9):517. http://dx.doi.org/10.1016/S1473-3099(02)00366-3

4. Hussein I. Will Egypt unleash another flu pandemic? Nature Middle East. 2015; Published online 12 March 2015.

5. Leventhal A, Ramlawi A, Belbiesi A, Sheikh S, Haddadin A, Husseini S, et al. Enhanced surveillance for detection and management of infectious diseases: regional collaboration in the middle East. Emerg Health Threats J. 2013;6. http://dx.doi.org/10.3402/ ehtj.v6io.19955

6. Holmberg M, Lundgren B. Framing post-pandemic preparedness: Comparing eight European plans. Glob Public Health. 2018 Jan;13(1):99-114. http://dx.doi.org/10.1080/17441692.2016.1149202

7. Cheng VC, To KK, Tse H, Hung IF, Yuen KY. Two years after pandemic influenza A/2009/H1N1: what have we learned? Clin Microbiol Rev. 2012;25(2):223-63. 
8. Kayali G, Webby RJ, Samhouri D, Mafi AR, Bassili A. Influenza research in the Eastern Mediterranean Region: The current state and the way forward. Influenza Other Respi Viruses. 2013;7(6):914-21. http://dx.doi.org/10.1111/irv.12136

9. Tavana A. Pandemic influenza A H1N1 in Iran and lessons learnt. Ann Trop Med Public Health. 2012;5(4):295-7. http://dx.doi. org/10.4103/1755-6783.102023

10. Gholami J, Hosseini SH, Ashoorkhani M, Majdzadeh SR. Lessons learned from HıN1 epidemic: The role of mass media in informing physicians. Int J Prev Med. 2011;2(1):32-7.

11. Seef S, Jeppsson A. Is it a policy crisis or it is a health crisis? The Egyptian context-analysis of the Egyptian health policy for the H1N1 flu pandemic control. Pan Afr Med J. 2013;14:59.

12. Kamal NN, Seedhom AE. Knowledge, attitude and practice of El-Minia university students towards pandemic HiN1, Egypt, 2009. J Public Health (Bangkok). 2011;19(6):505-10. http://dx.doi.org/10.1007/s10389-011-0427-1

13. El-Bahnasawy MM, Elmeniawy NZ, Morsy TA. An interventional program for nursing staff on selected mass gathering infectious diseases at Hajj. J Egypt Soc Parasitol. 2014;44(2):405-24. http://dx.doi.org/10.12816/0006480

14. El Gaafary MM, Abd Elaziz KM, Abdel-Rahman AG, Allam MF. Concerns, perceived impacts and preparedness of health care workers in a referral hospital in Egypt in facing influenza (H1N1) epidemic. J Prev Med Hyg. 2010;51(3):105-9.

15. Abdelwhab EM, Hafez HM. An overview of the epidemic of highly pathogenic $\mathrm{H}_{5} \mathrm{~N} 1$ avian influenza virus in Egypt: epidemiology and control challenges. Epidemiol Infect. 2011;139(5):647-57. http://dx.doi.org/10.1017/So950268810003122

16. Shahid M. On the roads to HiN1 pandemic era: drive safe and fearless using colour-coded masks. Asian Pac J Trop Med. 2012;5(4):333-4. http://dx.doi.org/10.1016/S1995-7645(12)60052-2

17. Janahi E, Awadh M, Awadh S. Public knowledge, risk perception, attitudes and practices in relation to the swine flu pandemic: A cross sectional questionnaire-based survey in Bahrain. Int J Collab Res Intern Med Public Health. 2011;3(6):451-64.

18. Ullah R, Zaman G, Islam S. Multiple control strategies for prevention of avian influenza pandemic. Scientific World Journal. 2014; 2014: 949718.

19. Rihan FA, Anwar MN, Sheek-Hussein M, Denic S. (2012). SIR model of swine influenza epidemic in Abu Dhabi: Estimation of vaccination requirement. Journal of Public Health Frontier 1; 85-89.

20. Leventhal A, Ramlawi A, Belbiesi A, Balicer RD. Regional collaboration in the Middle East to deal with $\mathrm{H}_{5} \mathrm{~N}_{1}$ avian flu. BMJ. 2006;333(7573):856-8. http://dx.doi.org/10.1136/bmj.38994.420926.80

21. Ahmed F, Al Hosani F, Al Mannaie A, Harrison O. Early outcomes of pandemic influenza ( $\mathrm{H} 1 \mathrm{N1}) 2009$ surveillance in Abu Dhabi Emirate, May-August 2009. East Mediterr Health J. 2012;18(1):31-6. http://dx.doi.org/10.26719/2012.18.1.31

22. Al Hajjar S, McIntosh K. The first influenza pandemic of the 21st century. Ann Saudi Med. 2010;30(1):1-10. http://dx.doi. org/10.5144/0256-4947.59365

23. Al-Muharrmi Z. Understanding the Influenza A H1N1 2009 Pandemic. Sultan Qaboos Univ Med J. 2010;10(2):187-95.

24. Ungchusak K, Sawanpanyalert P, Hanchoworakul W, Sawanpanyalert N, Maloney SA, Brown RC, et al. Lessons learned from influenza $\mathrm{A}(\mathrm{H1N} 1)$ pdmo9 pandemic response in Thailand. Emerg Infect Dis. 2012;18(7):1058-64. http://dx.doi.org/10.3201/ eid1807.110976

25. Breiman RF, Nasidi A, Katz MA, Kariuki Njenga M, Vertefeuille J. Preparedness for highly pathogenic avian influenza pandemic in Africa. Emerg Infect Dis. 2007;13(10):1453-8. http://dx.doi.org/10.3201/eid1310.070400

26. Ortu G, Mounier-Jack S, Coker R. Pandemic influenza preparedness in Africa is a profound challenge for an already distressed region: analysis of national preparedness plans. Health Policy Plan. 2008;23(3):161-9. http://dx.doi.org/10.1093/heapol/cznoo4

27. Al-Muharrmi Z. Understanding the Influenza A HiN1 2009 Pandemic. Sultan Qaboos Univ Med J. 2010;10(2):187-95.

28. Nikolay B, Salje H, Sturm-Ramirez K, Azziz-Baumgartner E, Homaira N, Ahmed M. Evaluating Hospital-Based Surveillance for Outbreak Detection in Bangladesh. Analysis of Healthcare Utilization Data. 2017;14(1):e1002218.

29. Coker R, Mounier-Jack S. Pandemic influenza preparedness in the Asia-Pacific region. Lancet. 2006;368(9538):886-9. http://dx.doi.org/10.1016/So140-6736(06)69209-X

30. Monto AS. Vaccines and antiviral drugs in pandemic preparedness. Emerg Infect Dis. 2006;12(1):55-60. http://dx.doi.org/10.3201/ eid1201.051068

31. Putthasri W, Lertiendumrong J, Chompook P, Tangcharoensathien V, Coker R. Capacity of Thailand to contain an emerging influenza pandemic. Emerg Infect Dis. 2009;15(3):423-32. http://dx.doi.org/10.3201/eid1503.080872 